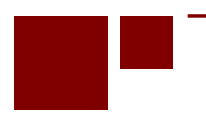

C E N T E R for

RETIREMENT

RE S E A R C H

at BOSTON COLLEGE

\title{
DO STATE AND LOCAL GOVERNMENT EMPLOYEES SAVE OUTSIDE OF THEIR DEFINED BENEFIT PLANS WHEN THEY NEED TO?
}

\author{
Laura D. Quinby and Geoffrey T. Sanzenbacher
}

CRR WP 2020-17

November 2020

\author{
Center for Retirement Research at Boston College \\ Hovey House \\ 140 Commonwealth Avenue \\ Chestnut Hill, MA 02467
}

Tel: 617-552-1762 Fax: 617-552-0191

https://crr.bc.edu

Laura D. Quinby is a senior research economist at the Center for Retirement Research at Boston College (CRR). Geoffrey T. Sanzenbacher is an associate professor of the practice of economics at Boston College and a research fellow at the CRR. The research reported herein was derived in whole or in part from research activities performed pursuant to a grant from the U.S. Social Security Administration (SSA) funded as part of the Retirement and Disability Research Consortium. The opinions and conclusions expressed are solely those of the authors and do not represent the opinions or policy of SSA, any agency of the federal government, or Boston College. Neither the United States Government nor any agency thereof, nor any of their employees, make any warranty, express or implied, or assumes any legal liability or responsibility for the accuracy, completeness, or usefulness of the contents of this report. Reference herein to any specific commercial product, process or service by trade name, trademark, manufacturer, or otherwise does not necessarily constitute or imply endorsement, recommendation or favoring by the United States Government or any agency thereof.

(C) 2020, Laura D. Quinby and Geoffrey T. Sanzenbacher. All rights reserved. Short sections of text, not to exceed two paragraphs, may be quoted without explicit permission provided that full credit, including $\odot$ notice, is given to the source. 


\begin{abstract}
About the Center for Retirement Research
The Center for Retirement Research at Boston College, part of a consortium that includes parallel centers at the National Bureau of Economic Research, the University of Michigan, and the University of Wisconsin-Madison, was established in 1998 through a grant from the U.S. Social Security Administration. The Center's mission is to produce first-class research and forge a strong link between the academic community and decision-makers in the public and private sectors around an issue of critical importance to the nation's future. To achieve this mission, the Center conducts a wide variety of research projects, transmits new findings to a broad audience, trains new scholars, and broadens access to valuable data sources.
\end{abstract}

Center for Retirement Research at Boston College

Hovey House

140 Commonwealth Ave

Chestnut Hill, MA 02467

Tel: 617-552-1762 Fax: 617-552-0191

https://crr.bc.edu

Affiliated Institutions:

The Brookings Institution

Mathematica - Center for Studying Disability Policy

Syracuse University

Urban Institute 


\begin{abstract}
As state and local policymakers enact benefit cuts to reduce the cost of their pension systems, the life-cycle model suggests that workers will adjust by saving more on their own. But, whether workers actually respond to pension characteristics remains an open question. After all, income received far in the future may not be salient to young workers deciding how much of their earnings to consume in the present. To answer the question, this paper links the Survey of Income and Program Participation to the Public Plans Database and explores whether state and local workers consider the amount of their pension savings, the funded status of their plan, or their Social Security coverage when deciding whether to participate in a supplemental defined contribution (DC) plan.
\end{abstract}

The paper found that:

- Employees whose pensions provide less income are more likely to participate in a supplemental DC plan, but the effect is small.

- Members of poorly funded pension plans are not more likely to participate in supplemental plans than members of well-funded plans.

- Employees without Social Security coverage are not compensating with greater participation in supplemental plans.

The policy implications of the findings are:

- If state and local employers are forced to further curtail their pensions, employees are unlikely to replace that income with outside savings.

- In the event that poorly funded pension plans end up reducing retirement income for current employees, those employees are unlikely to have been saving more in anticipation.

- In short, states and localities - especially those whose workers are not covered by Social Security - should not count on outside savings to replace pension income. 


\section{Introduction}

The savings behavior of public sector workers can be easy to overlook because a common narrative holds that they spend a full career in government and retire with substantial defined benefit (DB) pensions. ${ }^{1}$ But, in practice, the amount of DB wealth earned by state and local workers varies widely across jurisdictions, as well as across workers in the same jurisdiction. For example, benefits for new hires were cut back as governments grappled with fiscal pressures after the 2008 financial crisis, and further cuts may be looming in a few plans with a history of poor funding. ${ }^{2}$ Similarly, 25 percent of state and local workers are not covered by Social Security on their current job, and their DB plans often do not fully replace benefits they would have received under the program. ${ }^{3}$ And, roughly 45 percent of public employees will leave their jobs without even vesting in their DBs. ${ }^{4}$ In other words, a variety of reasons exist for even state and local workers to augment their pensions with outside savings.

This study asks whether state and local workers consider the amount of savings in their DB pension, the funded status of their plan, and their Social Security coverage when deciding whether to participate in supplemental defined contribution (DC) plans. ${ }^{5}$ Although a simple lifecycle model predicts that employees should react to variation in their pension income by adjusting their outside saving, whether this prediction holds in practice remains a subject of debate. Since pensions are paid out far in the future, they may not be salient to young workers deciding how much of their earnings to consume in the present. Or, workers may simply be at a corner solution - they would save less for retirement if they could, but their pension contributions cannot be reallocated.

To relate supplemental saving to the characteristics of primary DB plans, this paper merges data from the Survey of Income and Program Participation (SIPP) and the Public Plans Database (PPD). The SIPP contains data on the household finances, retirement saving, and Social Security coverage of state and local workers, while the PPD provides information on the benefit parameters and funded status of their DB pensions. A regression analysis is used to see if

\footnotetext{
${ }^{1}$ For example, see Beshears et al. (2011).

2 See Aubry, Munnell, and Wandrei (2020) and Aubry, Crawford, and Wandrei (2017).

${ }^{3}$ See Quinby, Aubry, and Munnell (2020) and Munnell et al. (2012).

${ }^{4}$ See Munnell et al. (2012).

${ }^{5}$ Although rarely considered in discussions of public sector retirement benefits, most state and local workers have access to supplemental plans (Hoops, Stefanescu, and Vidangos 2015). As of June 2020, state and local 457 and 403(b) plans (the dominant plan types) held $\$ 455$ billion in assets (Board of Governors of the Federal Reserve System, Financial Accounts of the United States).
} 
otherwise similar workers save more when their pensions provide less income, are poorly funded, and lack Social Security coverage.

The results suggest that workers respond modestly to salient pension provisions, such as the employee contribution rate, but not to more opaque characteristics, such as funding. For example, a 10-percentage-point decrease in the required employee contribution rate or the employer portion of the pension normal cost is predicted to increase participation in a supplemental DC plan by 4.6 and 1.9 percentage points, respectively. Yet, workers do not respond to a low pension funded ratio or to their lack of Social Security coverage by saving more in a supplemental DC plan.

The rest of the paper proceeds as follows. The first section describes what we know about the interaction between saving through DB pensions (employer pensions and Social Security) and saving through other means. The second section discusses the SIPP and PPD data used in this project, including how they are merged together. The third section describes the empirical methodology. The fourth section presents the results on the relationship between supplemental savings and three other determinants of retirement income: pension savings, the plan's funded ratio, and Social Security coverage. The final section concludes that if states and localities hope that their workers will make up for reduced pension income through supplemental savings, that hope may be ill-founded.

\section{Background}

Although DB pensions are the primary retirement plan for the vast majority of state and local government employees, all state workers and most local workers also have access to supplemental DC plans, namely 457s, 401(k)s, 401(a)s, and 403(b)s. ${ }^{6}$ To date, only a handful of case studies have explored these supplemental plans (Clark et al. 2016; Anderson and Collins 2017; and Clark and Pelletier 2019), with no general examination of the potential interaction between supplemental savings, DB pension features, and Social Security coverage.

In theory, a simple life-cycle model predicts that state and local workers will respond to a one-dollar increase in DB pension savings by decreasing their supplemental savings by one

\footnotetext{
${ }^{6}$ State and local governments often refer to these programs as "deferred compensation" plans. A survey of publicly available annual reports and plan websites reveals that all state governments and many large cities and school districts - including Austin, Chicago, Denver, Los Angeles, New York City, and San Francisco - currently offer these plans to their employees.
} 
dollar. ${ }^{7}$ In other words, a person would decrease their outside savings so as to hold constant their marginal utility of consumption over their lifetime. In practice, however, behavior is likely to deviate from this simple prediction. In particular, state and local workers may not be aware of how much saving is taking place through their DB pension. Whereas workers probably notice the required employee contribution that is deducted from their paycheck every month, they may not understand how much income the pension, which is partially funded through employer contributions, ultimately provides or the plan's funded status. Indeed, prior studies show that 50 percent of private sector workers are not even sure if they have a DB or a DC plan. ${ }^{8}$ Moreover, DB pensions often cannot be borrowed against, so more generous benefits may not be met onefor-one with lower liquid savings, which also serve as a hedge against risk. ${ }^{9}$ In the end, the relationship between pension income and supplemental savings is largely an empirical question.

The literature offers mixed messages on the extent to which workers respond. Supporting the simple prediction, Gale (1998) finds that more pension wealth is associated with lower nonpension net worth in early data from the Survey of Consumer Finances. Engelhardt and Kumar (2009) use the Health and Retirement Study to show that households with more assets in an employer-sponsored retirement plan also have fewer assets outside of those plans. And a simulation exercise by Blau (2016) based on a life-cycle model comes to a similar conclusion, with DB and DC wealth crowding out other types of assets. While none of these studies focus on state or local workers, nor on the tradeoff between DB pensions and DC savings specifically, they all suggest that public employees may pay attention and adjust their outside savings. ${ }^{10}$

However, a few studies do not find the predicted relationship between wealth in employer-sponsored retirement plans and other types of savings. For example, in an earlier analysis of the Health and Retirement Study, Gustman and Steinmeier (1999) find limited evidence that DB and DC plans crowd out other savings. Meanwhile, Slavov et al. (2019) instead focus on crowd out due to Social Security wealth, and also do not find significant evidence of displaced saving. ${ }^{11}$ Finally, Chetty et al. (2014) use data from Denmark to identify

\footnotetext{
${ }^{7}$ Assuming that the DB plan earns the same investment return as the worker's supplemental savings. Feldstein and Liebman (2002) summarize the classic model.

${ }^{8}$ Gustman, Steinmeier, and Tabatabai (2010).

${ }^{9}$ This point is made in Gale (1998).

${ }^{10}$ All of these studies use U.S. data. Studies using data outside of the U.S. have also found evidence of crowd out, including, for example, Hurd, Michaud, and Rohwedder (2012), Lachowska and Myck (2018), and Van Santen (2019).

${ }^{11}$ However, the study's authors are careful to note the large standard errors of their estimates.
} 
the factors that affect retirement saving. That study reports that efforts to subsidize retirement savings did crowd out other savings, as workers who were aware of the change (a relatively small share) shifted their assets towards the subsidized accounts. However, automatically increasing retirement contributions did not result in crowd out, as people were generally passive towards their other savings decisions. To the extent that recent state and local pension reforms may not be salient to workers, Chetty et al. suggests that a difference in pension saving may have no effect on saving outside the DB plan.

Given the lack of clarity in the literature, and the immediate policy relevance of state and local government pensions, this paper investigates how public sector workers respond to various characteristics of their primary DB pension: the contribution rate, funded ratio, and Social Security coverage. The next three sections describe the empirical analysis and results.

\section{Data}

This section describes the data used in this analysis, starting with the individual-level SIPP data, continuing to the plan-level PPD data, and concluding with the process of merging these two datasets.

\section{Survey of Income and Program Participation (SIPP)}

The SIPP is collected by the U.S. Census. The data consist of household-level panels that follow the individuals within a sampled household for two-and-a-half to four years. The data collected for each panel consist of a core module of questions asked every four months and a series of topical modules asked once or twice during the panel. This paper relies primarily on SIPP data covering the years 2003-2012, corresponding to the specific waves of the 2001, 2004, and 2008 panels that include the "Retirement and Pension Plan Coverage" topical module. ${ }^{12}$

Data from the core and topical modules are combined to construct a sample of full-time state and local workers who are eligible for their employers' pension based on their hours

\footnotetext{
12 This module was included in wave 7 of the 2001 and 2004 panels, and waves 3 and 11 of the 2008 panel. Although another SIPP panel launched in 2014, the main analysis does not use these data because information on Social Security coverage was no longer collected due to the survey's redesign. Nevertheless, the analysis has been performed with these 2014 data (and therefore without information on Social Security coverage), and the results are similar to those presented here. These additional results are available upon request.
} 
worked and occupation. ${ }^{13}$ The SIPP is also used to construct the dependent variables for the analysis, which relate to individuals' saving behavior outside of their DB pensions. The primary dependent variable is participation in a supplemental DC plan. State and local workers are considered to be participating in a supplemental DC plan if they indicate participation in more than one retirement plan (workers whose primary plan is a DC are not included in the analysis). ${ }^{14}$ Of course, this dependent variable is somewhat narrow, since it only reflects saving through one particular avenue and would fail to pick up household responses if spouses are the ones who adjust their saving. Fortunately, the SIPP also contains data on household retirement savings in its "Annual Income and Retirement Accounts" topical module. Therefore, this study also examines how pension income and funded status relate to the presence of any household retirement savings outside of the DB plan.

Another useful aspect of the SIPP is that it asks respondents whether they are covered by Social Security. In theory, workers without Social Security coverage are expected to save more outside their DB pensions, since those "FICA-replacement" DBs often do not fully replace the value of the program, relative to covered colleagues. ${ }^{15}$ It is worth noting that the PPD (discussed below) also contains data on Social Security coverage, and especially in the earlier panels suggests a lower rate of coverage than the SIPP (see Figure 1). However, the SIPP data reflect workers' own perceptions - whereas the PPD is administrative - and perceptions are most likely to inform behavior. ${ }^{16}$ Therefore, the SIPP version of the variable is used in the analysis.

The SIPP also contains information on worker demographics that may be correlated with both their propensity to save and the characteristics of their DB pension. The inclusion of such

\footnotetext{
${ }^{13}$ Individuals without enough information to determine eligibility or without information on pension participation are excluded from the analysis. In practice, workers whose primary plan is a defined contribution plan are also excluded; however, this restriction is implemented using the administrative PPD data on plan characteristics rather than self-reports.

${ }^{14}$ In general, the analysis does not categorize workers based on self-reported plan type (DB versus DC) because prior studies have shown that many workers are confused about the structure of their benefits (Gustman, Steinmeier, and Tabatabai 2010).

${ }^{15}$ As mentioned above, see Quinby, Aubry, and Munnell (2020) and Munnell et al. (2012) for details.

${ }^{16}$ This discrepancy could result from worker misperceptions about coverage. Specifically, in 2004, legislators acknowledged that many uncovered workers were not aware of the Windfall Elimination and Government Pension Offset provisions (WEP and GPO). A clause was added to the Social Security Protection Act requiring the SSA to inform uncovered public employees that their current FICA exemption will reduce their lifetime Social Security benefits. Starting in 2005, Form 1945 informs uncovered new hires that they will not earn Social Security benefits on this job, and that this job may trigger WEP and GPO provisions. Additionally, Social Security Statements issued after January 1, 2007 include a new section that notifies all workers in uncovered positions, who qualify for partial Social Security benefits, that their benefits may be reduced by the WEP or GPO (Hansen 2008).
} 
variables is potentially important. It has long been argued that one reason employers offer generous pensions is to attract forward-looking "savers" who are also "better" workers. ${ }^{17}$ Worker selection across employers based on propensity to save would bias the estimates in this paper, since it would appear that less generous pensions are correlated with less supplemental saving, not more as theory predicts. Controlling for worker characteristics such as education level and marital status - variables that may also be correlated with saving propensity - can mitigate this issue. ${ }^{18}$ Similarly, the SIPP contains data on workers' job characteristics aside from their pension, including their annual salary, tenure at their employer, and union status. In particular, the worker's sector and occupation will serve both as control variables in the empirical analysis, and also as a way to merge workers in the SIPP with their appropriate pension in the PPD. ${ }^{19}$

\section{Public Plans Database (PPD)}

The PPD is a comprehensive database of financial, governance, and plan design information for approximately 180 state and local defined benefit plans, spanning the years 2001 to 2017 (although only data from 2003-2012 are used in this study). The data are maintained by the Center for Retirement Research at Boston College in collaboration with the Center for State and Local Government Excellence and the National Association of State Retirement Administrators. The data cover over 85 percent of state and local government employees in the United States. The PPD provides several pieces of information that are useful for this study, including measures of pension savings and funded status.

For the purposes of this study, the main measure of pension savings used from the PPD is the employers' and the employees' required contributions to the normal cost of the pension. The normal cost is the present discounted value of the lifetime income that an employee accrues during the fiscal year, and is reported in the PPD as a percentage of the plan's total payroll. The sum of the employers' and employees' contribution is therefore a measure of the pension's

\footnotetext{
${ }^{17}$ Ippolito (2002) is a classic example of this literature, as he shows that workers who save in their employers' DC plans tend to have faster promotion, fewer disciplinary actions, and better performance reviews.

${ }_{18}$ The SIPP also contains basic data on gender, age, and race that can be used as controls.

${ }^{19}$ In particular, the SIPP data allow specific identification of university faculty, K-12 teachers, other employees in K-12 schools, corrections officers, and police officers/firefighters. Workers not falling into these categories are then labeled as "general" state or local employees. Most state and local pensions also classify members into these occupational groups.
} 
ability to replace working income. Practically, because the normal cost reflects a present value that depends on the discount rate used by the plan, this paper relies on a standardized normal cost that should only reflect the plan's benefit parameters. ${ }^{20}$

The normal cost does have two disadvantages as a measure of future pension income. The first disadvantage is that it reflects a pension-wide average, and thus does not perfectly reflect the situation of individual workers. For example, pension sponsors often cut benefits only for new hires, so that the normal cost overstates generosity for some workers and understates it for others. The second issue is that the normal cost may be less salient to workers than specific aspects of their pension, like their retirement age, which may be communicated to workers at hiring. Therefore, in some specifications, the analysis replaces the contribution rate variables with the appropriate benefit parameters based on employee tenure, occupation, and start date. In particular, these detailed data contain information on the benefit multiplier, the normal retirement age, and the pension's vesting period. ${ }^{21}$

In addition to data on pension savings, the PPD also records each pension funded ratio (the ratio of assets to liabilities). A low funded ratio could imply that promised benefits may need to be reduced in the future. For purposes of the analysis, the paper divides pensions into three terciles based on their funded ratios, and explores whether workers save more when their pensions are less funded. With data on pension income levels and fiscal health in hand, the final step is to merge the PPD data onto the SIPP data.

\section{Merging the SIPP and PPD}

Unfortunately, the SIPP data do not contain the information on each worker's specific employer that would allow an exact match with their pension plan in the PPD. Instead, the merge relies on three pieces of information: 1) state of residence; 2) status as a state or a local

\footnotetext{
${ }^{20}$ Although state and local trust funds are often invested in risky assets, the standardized normal cost variable used in this analysis reflects a 5-percent nominal discount rate, consistent with the assumed long-run return on safe investments in the 2019 Social Security Trustees Report. See Quinby and Sanzenbacher (2020) for a description of the standardization procedure. The employees' contribution to the normal cost is set by statute and does not depend on investment performance. In contrast, employers are responsible for providing legislated benefit levels regardless of investment performance. Hence, the standardized employer contribution rate simply subtracts the employee rate from the total standardized normal cost. In any case, the results are not sensitive to the assumption on the rate of return.

${ }^{21}$ The detailed benefit data were gathered by the Center for Retirement Research from Actuarial Valuations for all plans in the PPD in 2014.
} 
employee; and 3) occupation. ${ }^{22}$ This process works well for state-government employees because each worker can be uniquely paired to a state-administered plan based on occupation. For local teachers, the approach also works well since most teachers are covered by stateadministered umbrella plans (e.g., CALSTRS).

For local non-teachers (and teachers not covered by an umbrella plan), the merge is more difficult because the SIPP does not contain data on an individual's city of employment. Instead, local workers are assigned to "composite" plans that average the PPD data for all local pensions in the state, weighted by membership. This approach works well for workers in states dominated by a few local plans (e.g., in Illinois, the Chicago Teacher's Plan). However, in states with many local plans, this process may introduce measurement error. Therefore, the analysis will be conducted both with and without local workers.

Table 1 shows how the data are whittled down from the full sample of state and local workers in the SIPP to the final sample of full-time, pension-eligible workers matched to a full set of information in the PPD. In the end, the sample consists of over 10,000 state and local employees, representing every major occupational group (see Figure 2 for occupational groupings). The average member of the sample is mid-career, married, and college educated. About 21 percent report participation in a supplemental DC plan, and those who are participating appear fairly similar to those who are not, albeit with slightly higher tenure, earnings, and education (see Table 2).

\section{Empirical Approach}

Regression analyses are conducted on the merged data relating savings outside of DB pensions to DB savings and funded status, Social Security coverage, and the other controls mentioned above. The first set of regressions uses participation in a supplemental DC plan as a binary dependent variable in a linear probability model. The main equation for this set of regressions is:

$$
P_{i, t}=\beta_{0}+\beta_{1} G B_{i, t}+\alpha X_{i, t}+\gamma J C_{i, t}+\tau_{i}+\varepsilon_{i}
$$

Where, $P_{i, t}$ equals one if employee $i$ participates in a supplemental DC plan in year $t$. The vector $G B_{i, t}$ contains variables related to the individual's government pension. In the main

\footnotetext{
${ }^{22}$ The merge assumes that workers work within the state they live.
} 
specification, this vector includes controls for the employer's contribution to the standardized normal cost (as a percentage of salary), the employee's required contribution rate, self-reported Social Security coverage, and the funded-status tercile of the individual's plan (a plan in the bottom third is the base case). ${ }^{23}$ Although in principle the employer and employee contribution rates both fund the same retirement income, workers may be more responsive to their own contributions.

Other controls in equation (1) include, $X_{i}$, a vector of demographic information containing employee age, employee age squared, marital status, gender, race, and education. Similarly, $J C_{i}$ is a vector of job characteristics that includes the employee's tenure with their current employer, their status as a union member, their sector of employment (state or local), and whether they are a police officer, corrections officer, teacher, school employee, or university employee (general employment is the base case). This vector also includes the individual's total compensation - defined as annual salary plus the employer contribution to the standardized normal cost plus the employer portion of Social Security payroll taxes, if applicable - which the life-cycle model predicts should drive saving. ${ }^{24}$ Lastly, the regression includes a vector of year fixed effects, $\tau_{i}$. Inference is conducted using robust standard errors that are clustered at the household level. ${ }^{25}$

In addition to this main specification, several variations are run off of equation (1). As mentioned in the data section, in some specifications the contributions to the normal cost are replaced with individual-specific benefit parameters - the benefit multiplier, the normal retirement age, and the length of time it takes to be vested. Additionally, equation (1) is run with a few alternative samples. One specification addresses the vesting structure inherent in publicsector DB plans. In most cases, participants who leave before their vesting period is over - a period of often five to ten years - receive only their own contributions plus some low rate of

\footnotetext{
${ }^{23}$ The regression also controls for whether the plan has a hybrid DB/DC design.

${ }^{24}$ The classic life-cycle model predicts that workers smooth consumption over time, so that increased compensation and consumption today should be accompanied by increased consumption tomorrow through saving. For complete accuracy, the total compensation variable included in this regression should also include the employer cost of nonpension benefits, particularly employer contributions to health insurance premiums. However, neither the SIPP nor the PPD contain information on these costs; data on employer-paid health premiums for state employees are available for 2013 from the Pew Charitable Trusts and the John D. and Catherine T. McArthur Foundation (2014). Including these premiums as proxies reduced the sample size without changing the results, so the main analysis omits them.

${ }^{25}$ In most panels, each household only appears once. However, in the 2008 panel, each household appears twice because the retirement plan topical module was asked twice.
} 
interest. ${ }^{26}$ Therefore, this specification separates vested from non-vested employees under the hypothesis that non-vested workers may be less responsive to their employer's contribution to the normal cost, since there is some probability they will not receive a benefit aside from their own contributions.

Another specification focuses only on workers who report having a DB plan in the SIPP, since those who mistakenly claim to have a DC (but actually participate in a DB according to the PPD's administrative data) presumably do not respond to the plan's generosity. Similarly, a regression is run excluding local workers, since the merge procedure for the PPD requires more assumptions for this group.

A final specification broadens the analysis to examine total household retirement saving, since the dependent variable in equation (1) assumes that workers only save through their own supplemental DC plan. This broad specification re-runs equation (1) with a new dependent variable that includes any household retirement savings outside of the DB plan. ${ }^{27}$ The new dependent variable includes supplemental DC savings as well as savings attributed to a spouse, and controls for the spouse's demographic and job characteristics in addition to the worker's.

\section{Results}

This section presents the results, first looking at participation in a supplemental plan using the full sample, then for subsets of the full sample, and then using an alternative dependent variable that captures household retirement saving.

\section{Participation in a Supplemental Plan: Full Sample}

The first column of Table 3 contains regression results for the full sample using the employers' and employees' contributions to the standardized normal cost as the measure of pension savings. The results suggest that workers do respond to the income provided by their primary DB plan. For example, a one-percentage-point increase in the employer's normal cost rate is associated with a 0.19 -percentage-point decrease in the probability of saving in a

\footnotetext{
${ }^{26}$ See Munnell, Aubry, Hurwitz, and Quinby (2012) for detail.

${ }^{27}$ Broadening the savings concept even further to include all household financial assets yields similar results.
} 
supplemental plan. ${ }^{28}$ And, as expected, the coefficient on the employee rate is larger: a onepercentage-point increase in the required employee contribution rate is associated with a 0.46percentage-point reduction in the probability of saving in a supplemental pension. ${ }^{29}$ However, while the coefficients above are in the direction expected, the magnitudes are small. For example, a one-standard-deviation increase in the employer normal cost rate (6 percentage points) is only associated with a 1.1-percentage-point decrease in the participation rate, relative to a baseline of 21 percent. Similarly, a one-standard-deviation increase in the employee contribution rate (3 percentage points) is associated with a 1.4-percentage-point decrease in the participation rate.

Table 3 also suggests that workers whose pensions are in the second and highest fundedratio terciles are no more or less likely to save than workers whose pensions are poorly funded. ${ }^{30}$ This finding suggests that workers in the least well-funded plans may be unprepared should sponsors cut benefits for existing workers in order to reduce costs. Moreover, the coefficient on Social Security coverage is very close to zero, and also statistically insignificant. Since uncovered state and local workers sometimes participate in pensions that fail to fully replace the program, this result suggests that they may end up less prepared for retirement than their covered counterparts.

The other coefficients in the regression are largely intuitive. For example, workers with higher total compensation are significantly more likely to save in supplemental plans - a onestandard-deviation increase in total compensation (a 63-percent increase from the mean) is associated with a 4.4-percentage-point increase in the probability of saving in a supplemental DC plan. Additionally, workers with longer tenure, who are older, and who have more education are all significantly more likely to save in a supplemental plan than others.

The second column of Table 3 repeats the analysis, but replaces the required employee contribution rate and the employer normal cost rate with the plan's benefit multiplier, retirement age, and vesting period (in years). ${ }^{31}$ The coefficients on the benefit multiplier and retirement age are in the expected direction and statistically significant; a one-standard-deviation increase in the

\footnotetext{
${ }^{28}$ Note that the employer and employee contribution rate variables range from 0 to 1 , so the raw regression coefficients correspond to a 100-percentage-point increase in the rate.

${ }^{29}$ The difference between the two coefficients is only marginally statistically significant (p-value of 0.073 ).

${ }^{30}$ The average funded ratio in the bottom tercile is 64 percent; compared to 83 and 100 percent in the middle and highest terciles, respectively.

31 This specification drops 71 observations (less than 1 percent of the sample) due to missing benefit parameters.
} 
benefit multiplier (a change of 0.004) leads to a 1.7-percentage-point reduction in the probability of supplemental saving, while a one-standard-deviation increase in the normal retirement age (a change of 5 years) leads to a 1.6-percentage-point increase in the probability of participation. ${ }^{32}$ The coefficient on the vesting period is not statistically significant. And while the coefficients on the benefit multiplier and the full retirement age suggest that reductions in pension income would be met with increased participation in supplemental plans, again the effects are relatively small.

\section{Participation in Supplemental Plan: Select Subsamples}

To ensure that the results are not overly sensitive to the sample chosen, Table 4 shows several iterations of the main specification where the sample is restricted. For convenience of comparison, the first column repeats the results from the first column of Table 3 , in which the employer normal cost rate was used instead of specific pension features.

One possibility for the small estimated effects is that workers who are not yet vested in the plan do not react to its generosity, drowning out the response of those who are vested. Therefore, the second column of Table 4 shows the results only for employees who have worked long enough at their employer to be vested. The results are fairly similar, although vested employees do appear more responsive to the employer contribution to the standardized normal cost than non-vested employees. A one-percentage-point increase in the employer normal cost rate in this specification is associated with a 0.28 -percentage-point reduction in the probability of supplemental saving, compared to 0.19 percentage points in the main specification. ${ }^{33}$ Still, this finding suggests that a one-standard-deviation increase would increase participation by just 1.7 percentage points, relative to a 21-percent baseline, and thus does not seem to contradict the main finding from the full sample of a relatively small overall effect.

Another possibility is that workers are more responsive than the regressions suggest because the independent variables - in this case pension savings - are measured with error. ${ }^{34}$

\footnotetext{
${ }^{32}$ Recall that an increase in the retirement age decreases pension wealth.

${ }^{33}$ Indeed, running a regression on the full sample that interacts the employer and employee contribution rate variables with a binary indicator for vested status (available on request) reveals that non-vested workers do not respond to the employer normal cost rate at all, whereas vested workers respond as indicated in the main text. This difference is statistically significant.

${ }^{34}$ Measurement error in the independent variable can cause attenuation of the coefficient towards zero.
} 
While the PPD comes from administrative data and thus should not contain error, the merge process onto the SIPP is not perfect, especially for local workers. The third column of Table 4 therefore drops all local workers, and runs the main specification on state workers only. ${ }^{35}$ Again, the coefficients are similar to the main specification, although in this case they are not statistically significant due to the loss of sample size.

A final possibility is that workers who understand the structure of their DB pension do respond strongly to its provisions, whereas those who do not understand it fail to respond. The fourth column of Table 4 therefore focuses only on workers in the SIPP who claim to have a DB plan. ${ }^{36}$ This specification results in estimates that, for the employee contribution rate, are the most different from the original. A one-percentage point increase in the employer and employee contribution rates is associated with a 0.27 and 0.71 -percentage-point-reduction in the probability of supplemental savings, respectively. Still, the main finding of a small response seems to hold. However, one more possibility worth exploring is that workers respond by saving through other means.

\section{Household Retirement Savings}

Table 5 shows two final regressions, trading out the dependent variable of participating in a supplemental plan with a binary variable indicating the household has any retirement savings outside of a DB. Roughly 30 percent of households in the full sample have some retirement assets outside of their DB pension, compared to just 21 percent of workers who participate in a supplemental plan.

Despite the broader definition, the results are fairly similar to the main specification. When examining all households in the first column of Table 5, a one-percentage-point increase in the employer normal cost rate reduces workers' likelihood of having any outside retirement savings by 0.22 percentage points. A one-percentage-point increase in the employee contribution to the normal cost decreases the likelihood of outside savings by 0.68 percentage points. The comparable estimates for supplemental DC savings only were 0.19 and 0.46

\footnotetext{
35 This sample restriction also confirms that the results are not driven by lack of access to an employer-sponsored supplemental DC plan, since all state employers offer these accounts.

${ }^{36}$ Even though the PPD suggests that all employees in the sample actually do have a DB plan, only about 65 percent of the full sample report having a DB, with the rest reporting a DC.
} 
percentage points respectively. So, while the coefficients are slightly larger when this broader form of savings is considered, the overall relationship is still fairly small.

Since one of the greatest advantages of examining all forms of outside retirement savings is the ability of a spouse to respond, the second column of Table 5 looks only at married couples, controlling for the demographic and job characteristics of the spouse. The resulting estimates are nearly identical to the full sample. A one-percentage-point increase in employer normal cost rate would reduce the probability of outside retirement savings by 0.19 percentage points. Increasing the employee contribution rate by one percentage point would reduce the probability of outside retirement savings by 0.53 percentage points. It seems that whatever dependent variable or sample is used, the basic result is the same - state and local workers respond as expected, but at a low magnitude.

\section{Conclusion}

The life-cycle model suggests that state and local workers should respond to reductions in pension income, low funded ratios, and/or a lack of Social Security coverage through increased savings outside of their DB plans. While such saving could occur through many vehicles - such as IRAs, housing, and debt reduction - most public employees have access to tax-deferred defined contribution accounts sponsored by their employers. Combined with variation in primary plan design, these supplemental accounts offer a way to explore whether state and local workers respond as predicted by the classic model.

The results from this paper suggest that workers with less pension savings - whether measured by normal cost or by specific benefit parameters - are more likely to save in supplemental plans. But, the effects are relatively small. Furthermore, workers do not seem to respond to low funded ratios nor to a lack of Social Security coverage. Overall, state and local workers are likely to have fewer resources in retirement should states and localities continue to cut generosity for new hires or be forced to cut benefits for current workers. 


\section{References}

Anderson, Drew M. and J. Michael Collins. 2017. "Can Knowledge Empower Women to Save More for Retirement?” Working Paper 2017-12. Chestnut Hill, MA: Center for Retirement Research at Boston College.

Aubry, Jean-Pierre, Caroline V. Crawford, and Kevin Wandrei. 2017. "Stability in Overall Pension Plan Funding Masks a Growing Divide." State and Local Plans Issue in Brief 62. Chestnut Hill, MA: Center for Retirement Research at Boston College.

Aubry, Jean-Pierre, Alicia H. Munnell, and Kevin Wandrei. 2020. "2020 Update: Market Decline Worsens the Outlook for Public Plans." State and Local Plans Update. Chestnut Hill, MA: Center for Retirement Research at Boston College.

Beshears, John, James J. Choi, David Laibson, and Brigitte C. Madrian. 2011. "Behavioral Economics Perspectives on Public Sector Pension Plans." Journal of Pension Economics and Finance 10(2): 315-336.

Blau, David M. 2016. "Pensions, Household Saving, and Welfare: A Dynamic Analysis of Crowd Out." Quantitative Economics 7(1): 193-224.

Chetty, Raj, John N. Friedman, Soren Leth-Petersen, Torben Heien Nielsen, and Tore Olsen. 2014. "Active vs. Passive Decisions and Crowd-Out in Retirement Savings Accounts: Evidence from Denmark." The Quarterly Journal of Economics 129(3): 1141-1219.

Clark, Robert L., Emma Hanson, Melinda Sandler Morrill, and Aditi Pathak. 2016. "Supplemental Plan Offerings and Retirement Savings Choices: An Analysis of North Carolina School Districts." Journal of Pension Economics and Finance 15(3): 333-355.

Clark, Robert L. and Denis Pelletier. 2019. "Impact of Defaults in Retirement Savings Plans: Public Employee Plans.” Working Paper 26234. Cambridge, MA: National Bureau of Economic Research.

Engelhardt, Gary V. and Anil Kumar. 2009. "Pensions and Household Wealth Accumulation." The Journal of Human Resources 46(1): 203-236.

Feldstein, Martin and Jeffrey Liebman. 2002. "Social Security." Handbook of Public Economics 4(chapter 32): 2245-2324.

Gale, William G. 1998. "The Effects of Pensions on Household Wealth: A Reevaluation of Theory and Evidence." Journal of Political Economy 106(4): 706-723.

Gustman, Alan L. and Thomas L. Steimeier. 1999. "Effects of Pensions on Savings: Analysis with Data from the Health and Retirement Study." Carnegie-Rochester Conference Series on Public Policy 50: 271-324. 
Gustman, Alan L., Thomas L. Steinmeier, and Nahid Tabatabai. 2010. Pensions in the Health and Retirement Study. Cambridge, MA: Harvard University Press.

Hansen, Erik. 2008. "A Legislative History of the Social Security Protection Act of 2004." Social Security Bulletin 68(4): 41-52.

Hoops, Matthew, Irina Stefanescu, and Ivan Vidangos. 2015. "Defined-Contribution Pension Plans for State and Local Government Employees in the Financial Accounts of the United States." FEDs Notes. Washington, DC: Board of Governors of the Federal Reserve System.

Hurd, Michael, Pierre-Carl Michaud, and Susann Rohwedder. 2012. "The Displacement Effect of Public Pensions on the Accumulation of Financial Assets." Fiscal Studies 33(1): 107 128.

Ippolito, Richard A. 2002. "Stayers as "Workers" and "Savers": Toward Reconciling the Pension-quit Literature." Journal of Human Resources 37(2): 275-308.

Lachowska, Marta and Michal Myck. 2018. "The Effect of Public Pension Wealth on Saving and Expenditure.” American Economic Journal: Economic Policy 10(3): 284-308.

Munnell, Alicia H., Jean-Pierre Aubry, Josh Hurwitz, and Laura D. Quinby. 2012. "The Impact of Long Vesting Periods on State and Local Workers." State and Local Plans Issue in Brief 26. Chestnut Hill, MA: Center for Retirement Research at Boston College.

Pew Charitable Trusts and John D. and Catherine T. McArthur Foundation. 2014. "State Employee Health Plan Spending: An Examination of Premiums, Cost Drivers, and Policy Approaches." Report. Washington, DC.

Public Plans Database. 2001-2020. Center for Retirement Research at Boston College, Center for State and Local Government Excellence, and National Association of State Retirement Administrators.

Quinby, Laura D., Jean-Pierre Aubry, and Alicia H. Munnell. 2020. "Pensions for State and Local Government Workers Not Covered by Social Security: Do Benefits Meet Federal Standards?" Social Security Bulletin 80(3): 1-29.

Quinby, Laura D. and Geoffrey T. Sanzenbacher. 2020. "Do Pensions Matter for Recruiting State and Local Workers?" State and Local Government Review (forthcoming).

Slavov, Sita, Devon Gorry, Aspen Gorry, and Frank N. Caliendo. 2019. "Social Security and Saving: An Update." Public Finance Review 47(2): 312-348.

U.S. Social Security Administration. 2019. The Annual Report of the Board of Trustees of the Federal Old-Age and Survivors Insurance and Federal Disability Insurance Trust Funds. Washington, DC: U.S. Government Printing Office. 
Van Santen, Peter. 2019. "Uncertain Pension Income and Household Saving." Review of Income and Wealth 65(4): 908-929. 
Table 1. Derivation of the Analysis Sample, 2003-2012

\begin{tabular}{lc}
\hline Sample restriction & Number of observations \\
\hline State and local employees & 20,041 \\
Full-time with positive earnings & 14,750 \\
Reports employer plan and matched with PPD & 12,216 \\
Reports plan eligible & 11,889 \\
Hired before primary pension converted to DC & 11,840 \\
Matched with detailed benefit provisions & 11,822 \\
With non-missing data on all regression variables & 10,295 \\
\hline
\end{tabular}

Sources: Authors' estimates from the Survey of Income and Program Participation (SIPP) 2003-2012; and the Public Plans Database (PPD) 2003-2012.

Table 2. Sample Characteristics by Participation in a Supplemental Plan, 2003-2012

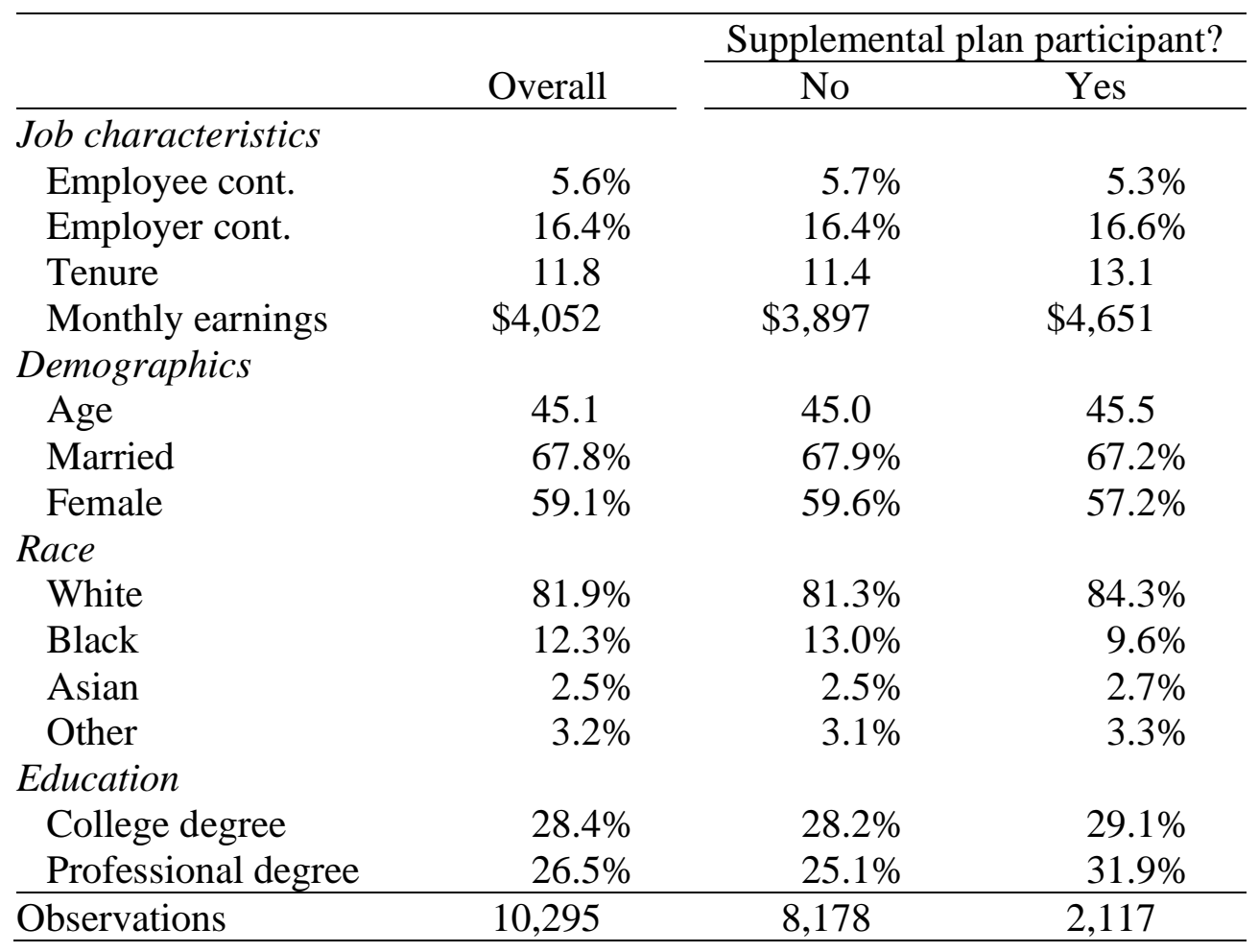

Sources: Authors' estimates from the SIPP 2003-2012; and the PPD 2003-2012. 
Table 3. Relationship between Select Characteristics and Participation in a Supplemental Plan

\begin{tabular}{|c|c|c|}
\hline \multirow[b]{2}{*}{ Variable } & \multicolumn{2}{|c|}{ Specification } \\
\hline & $(1)$ & $(2)$ \\
\hline \multirow[t]{2}{*}{ Employer contribution rate } & $-0.188 * * *$ & \\
\hline & $(0.0728)$ & \\
\hline \multirow[t]{2}{*}{ Employee contribution rate } & $-0.464 * * *$ & \\
\hline & $(0.144)$ & \\
\hline \multirow[t]{2}{*}{ Benefit multiplier } & & $-4.336 * * *$ \\
\hline & & $(1.085)$ \\
\hline \multirow[t]{2}{*}{ Normal retirement age } & & $0.00317 * * *$ \\
\hline & & $(0.00119)$ \\
\hline \multirow[t]{2}{*}{ Vesting period } & & -0.000356 \\
\hline & & $(0.00175)$ \\
\hline \multirow{2}{*}{$\begin{array}{l}\text { Reports Social Security } \\
\text { coverage }\end{array}$} & -0.00292 & -0.00302 \\
\hline & $(0.0113)$ & $(0.0114)$ \\
\hline \multirow[t]{2}{*}{ Lowest funding tercile } & 0.00322 & -0.00362 \\
\hline & $(0.0103)$ & $(0.0104)$ \\
\hline \multirow[t]{2}{*}{ Highest funding tercile } & 0.00102 & 0.0108 \\
\hline & $(0.0104)$ & $(0.0103)$ \\
\hline \multirow[t]{2}{*}{ Pension converted to hybrid } & $0.0194 *$ & 0.0122 \\
\hline & $(0.0108)$ & $(0.0112)$ \\
\hline \multirow[t]{2}{*}{ Log total compensation } & $0.0695 * * *$ & $0.0660 * * *$ \\
\hline & $(0.00855)$ & $(0.00841)$ \\
\hline \multirow[t]{2}{*}{ Current tenure } & $0.00226 * * *$ & $0.00322 * * *$ \\
\hline & $(0.000525)$ & $(0.000620)$ \\
\hline \multirow{2}{*}{ Union member } & $0.0292 * * *$ & $0.0202 * *$ \\
\hline & $(0.00899)$ & $(0.00892)$ \\
\hline \multirow[t]{2}{*}{ Local worker } & 0.00829 & 0.00879 \\
\hline & $(0.00922)$ & $(0.00930)$ \\
\hline \multirow[t]{2}{*}{ Police } & $0.0397 * *$ & $0.0556 * * *$ \\
\hline & $(0.0197)$ & $(0.0207)$ \\
\hline \multirow[t]{2}{*}{ Corrections } & -0.0364 & -0.0125 \\
\hline & $(0.0335)$ & $(0.0369)$ \\
\hline \multirow[t]{2}{*}{ Teacher } & $-0.0652 * * *$ & $-0.0637 * * *$ \\
\hline & $(0.0130)$ & $(0.0130)$ \\
\hline \multirow[t]{2}{*}{ School } & $-0.0633 * * *$ & $-0.0657 * * *$ \\
\hline & $(0.0116)$ & $(0.0117)$ \\
\hline \multirow[t]{2}{*}{ University } & $-0.0600 * * *$ & $-0.0615 * * *$ \\
\hline & $(0.0163)$ & $(0.0163)$ \\
\hline \multirow[t]{2}{*}{ Age } & $0.00874 * * *$ & $0.00870 * * *$ \\
\hline & $(0.00276)$ & $(0.00277)$ \\
\hline \multirow{2}{*}{ Age squared } & $-0.000104 * * *$ & $-0.000115 * * *$ \\
\hline & $(3.06 \mathrm{e}-05)$ & $(3.08 \mathrm{e}-05)$ \\
\hline
\end{tabular}


Table 3 (cont.). Relationship between Select Characteristics and Participation in a Supplemental Plan

\begin{tabular}{lcc}
\hline \multirow{2}{*}{ Variable } & \multicolumn{2}{c}{ Specification } \\
\cline { 2 - 3 } Married & $(1)$ & $(2)$ \\
& $\left(0.0180^{* *}\right.$ & $-0.0185^{* *}$ \\
Female & $0.00913)$ & $(0.00918)$ \\
& $(0.00901)$ & 0.0118 \\
Black & $-0.0453^{* * *}$ & $(0.00905)$ \\
& $(0.0117)$ & $-0.0422^{* * *}$ \\
Asian & -0.00206 & $(0.0118)$ \\
& $(0.0263)$ & -0.00698 \\
Other & 0.00350 & $(0.0263)$ \\
& $(0.0244)$ & 0.00166 \\
College degree & $0.0303^{* * *}$ & $(0.0246)$ \\
& $(0.0113)$ & $0.0288^{* *}$ \\
Professional degree & $0.0580^{* * *}$ & $(0.0114)$ \\
& $(0.0129)$ & $0.0570^{* * *}$ \\
Constant & $-0.494^{* * *}$ & $(0.0129)$ \\
& $(0.0870)$ & $-0.605^{* * *}$ \\
Observations & 10,295 & $(0.108)$ \\
R-squared & 0.035 & 10,224 \\
\end{tabular}

Notes: Robust standard errors are in parentheses. Stars indicate statistical significance: $* * *<0.01, * *<0.05, *$ $<0.10$.

Sources: Authors' estimates from the SIPP 2003-2012; and the PPD 2003-2012. 
Table 4. Relationship between Select Characteristics and Participation in a Supplemental Plan for Full Sample and Select Subsamples

\begin{tabular}{|c|c|c|c|c|}
\hline Variable & Full sample & Vested only & $\begin{array}{c}\text { State } \\
\text { workers only }\end{array}$ & Reports DB \\
\hline \multirow[t]{2}{*}{ Employer contribution rate } & $-0.188 * * *$ & $-0.277 * * *$ & -0.197 & $-0.266 * * *$ \\
\hline & $(0.0728)$ & $(0.0959)$ & $(0.127)$ & $(0.0984)$ \\
\hline \multirow[t]{2}{*}{ Employee contribution rate } & $-0.464 * * *$ & $-0.385 * *$ & -0.375 & $-0.706 * * *$ \\
\hline & $(0.144)$ & $(0.183)$ & $(0.236)$ & $(0.194)$ \\
\hline \multirow{2}{*}{$\begin{array}{l}\text { Reports Social Security } \\
\text { coverage }\end{array}$} & -0.00292 & 0.00515 & -0.0159 & 0.0147 \\
\hline & $(0.0113)$ & $(0.0146)$ & $(0.0190)$ & $(0.0147)$ \\
\hline \multirow[t]{2}{*}{ Lowest funding tercile } & 0.00322 & 0.00900 & -0.00899 & 0.00878 \\
\hline & $(0.0103)$ & $(0.0133)$ & $(0.0167)$ & $(0.0142)$ \\
\hline \multirow[t]{2}{*}{ Highest funding tercile } & 0.00102 & 0.0146 & 0.0140 & -0.000794 \\
\hline & $(0.0104)$ & $(0.0132)$ & $(0.0164)$ & $(0.0139)$ \\
\hline \multirow[t]{2}{*}{ Pension converted to hybrid } & $0.0194 *$ & $0.0242 *$ & 0.0274 & $0.0286 * *$ \\
\hline & $(0.0108)$ & $(0.0137)$ & $(0.0182)$ & $(0.0145)$ \\
\hline \multirow[t]{2}{*}{ Log total compensation } & $0.0695 * * *$ & $0.0868 * * *$ & $0.0564 * * *$ & $0.0844 * * *$ \\
\hline & $(0.00855)$ & $(0.0112)$ & $(0.0129)$ & $(0.0118)$ \\
\hline \multirow[t]{2}{*}{ Current tenure } & $0.00226^{* * *}$ & $0.00196 * * *$ & $0.00237 * * *$ & $0.00229 * * *$ \\
\hline & $(0.000525)$ & $(0.000719)$ & $(0.000852)$ & $(0.000689)$ \\
\hline \multirow[t]{2}{*}{ Union member } & $0.0292 * * *$ & $0.0239 * *$ & $0.0512 * * *$ & $0.0244 * *$ \\
\hline & $(0.00899)$ & $(0.0115)$ & $(0.0153)$ & $(0.0119)$ \\
\hline \multirow[t]{2}{*}{ Local worker } & 0.00829 & 0.0112 & & 0.0119 \\
\hline & $(0.00922)$ & $(0.0118)$ & & $(0.0122)$ \\
\hline \multirow[t]{2}{*}{ Police } & $0.0397 * *$ & 0.0376 & 0.0359 & $0.0550 * *$ \\
\hline & $(0.0197)$ & $(0.0257)$ & $(0.0505)$ & $(0.0256)$ \\
\hline \multirow[t]{2}{*}{ Corrections } & -0.0364 & -0.00295 & $-0.166 * * *$ & -0.0476 \\
\hline & $(0.0335)$ & $(0.0631)$ & $(0.0314)$ & $(0.0457)$ \\
\hline \multirow[t]{2}{*}{ Teacher } & $-0.0652 * * *$ & $-0.0975^{* * * *}$ & $-0.0756 * * *$ & $-0.0875 * * *$ \\
\hline & $(0.0130)$ & $(0.0172)$ & $(0.0220)$ & $(0.0170)$ \\
\hline \multirow[t]{2}{*}{ School } & $-0.0633 * * *$ & $-0.0683 * * *$ & $-0.0661 * * *$ & $-0.0833 * * *$ \\
\hline & $(0.0116)$ & $(0.0149)$ & $(0.0216)$ & $(0.0156)$ \\
\hline \multirow[t]{2}{*}{ University } & $-0.0600 * * *$ & $-0.0684 * * *$ & $-0.0671 * * *$ & $-0.0504 * *$ \\
\hline & $(0.0163)$ & $(0.0215)$ & $(0.0187)$ & $(0.0235)$ \\
\hline \multirow[t]{2}{*}{ Age } & $0.00874 * * *$ & 0.00318 & $0.0159 * * *$ & $0.0103 * * *$ \\
\hline & $(0.00276)$ & $(0.00452)$ & $(0.00433)$ & $(0.00379)$ \\
\hline \multirow[t]{2}{*}{ Age squared } & $-0.000104 * * *$ & $-5.30 \mathrm{e}-05$ & $-0.000184 * * *$ & $-0.000135 * * *$ \\
\hline & $(3.06 \mathrm{e}-05)$ & $(4.69 \mathrm{e}-05)$ & $(4.83 e-05)$ & $(4.18 \mathrm{e}-05)$ \\
\hline \multirow[t]{2}{*}{ Married } & $-0.0180 * *$ & $-0.0350 * * *$ & $-0.0272 *$ & $-0.0225^{*}$ \\
\hline & $(0.00913)$ & $(0.0120)$ & $(0.0144)$ & $(0.0122)$ \\
\hline \multirow[t]{2}{*}{ Female } & 0.0126 & $0.0275 * *$ & 0.00618 & 0.0116 \\
\hline & $(0.00901)$ & $(0.0115)$ & $(0.0144)$ & $(0.0121)$ \\
\hline
\end{tabular}


Table 4 (cont.). Relationship between Select Characteristics and Participation in a Supplemental Plan for Full Sample and Select Subsamples

\begin{tabular}{|c|c|c|c|c|}
\hline Variable & Full sample & Vested only & $\begin{array}{c}\text { State } \\
\text { workers only }\end{array}$ & Reports DB \\
\hline \multirow[t]{2}{*}{ Black } & -0.0453 & $-0.0424 * * *$ & $-0.0338 *$ & $-0.0594 * * *$ \\
\hline & $(0.0117)$ & $(0.0154)$ & $(0.0191)$ & $(0.0156)$ \\
\hline \multirow[t]{2}{*}{ Asian } & -0.00206 & 0.0239 & 0.000262 & -0.00876 \\
\hline & $(0.0263)$ & $(0.0362)$ & $(0.0402)$ & $(0.0378)$ \\
\hline \multirow[t]{2}{*}{ Other } & 0.00350 & 0.0184 & 0.0124 & 0.00517 \\
\hline & $(0.0244)$ & $(0.0327)$ & $(0.0372)$ & $(0.0340)$ \\
\hline \multirow[t]{2}{*}{ College degree } & $0.0303 * * *$ & $0.0383 * * *$ & 0.0249 & $0.0387 * *$ \\
\hline & $(0.0113)$ & $(0.0148)$ & $(0.0177)$ & $(0.0152)$ \\
\hline \multirow[t]{2}{*}{ Professional degree } & $0.0580 * * *$ & $0.0851 * * *$ & $0.0633 * * *$ & $0.0774 * * *$ \\
\hline & $(0.0129)$ & $(0.0171)$ & $(0.0204)$ & $(0.0169)$ \\
\hline \multirow[t]{2}{*}{ Constant } & $-0.494 * * *$ & $-0.478 * * *$ & $-0.512 * * *$ & $-0.546 * * *$ \\
\hline & $(0.0870)$ & $(0.136)$ & $(0.136)$ & $(0.121)$ \\
\hline Observations & 10,295 & 6,650 & 3,862 & 6,765 \\
\hline R-squared & 0.035 & 0.041 & 0.042 & 0.044 \\
\hline
\end{tabular}

Notes: Robust standard errors are in parentheses. Stars indicate statistical significance: $* * *<0.01, * *<0.05, *$ $<0.10$.

Sources: Authors' estimates from the SIPP 2003-2012; and the PPD 2003-2012. 
Table 5. Relationship between Select Characteristics and Having Any Retirement Savings

\begin{tabular}{|c|c|c|}
\hline \multirow[b]{2}{*}{ Variables } & \multicolumn{2}{|c|}{ Specification } \\
\hline & Full sample & Married only \\
\hline \multirow[t]{2}{*}{ Employer DB normal cost rate } & $-0.222 * * *$ & $-0.191 * *$ \\
\hline & $(0.0797)$ & $(0.0929)$ \\
\hline \multirow[t]{2}{*}{ Employee DB contribution rate } & $-0.677 * * *$ & $-0.534 * * *$ \\
\hline & $(0.159)$ & $(0.186)$ \\
\hline \multirow[t]{2}{*}{ Reports Social Security coverage } & 0.0119 & 0.00264 \\
\hline & $(0.0127)$ & $(0.0149)$ \\
\hline \multirow[t]{2}{*}{ Lowest funding tercile } & 0.0008 & -0.0158 \\
\hline & $(0.0116)$ & $(0.0137)$ \\
\hline \multirow[t]{2}{*}{ Highest funding tercile } & 0.0121 & 0.0171 \\
\hline & $(0.0114)$ & $(0.0134)$ \\
\hline \multirow[t]{2}{*}{ Pension converted to hybrid } & 0.00483 & 0.0136 \\
\hline & $(0.0115)$ & $(0.0133)$ \\
\hline \multirow[t]{2}{*}{ Log total compensation } & $0.0677 * * *$ & $0.0726 * * *$ \\
\hline & $(0.0106)$ & $(0.0127)$ \\
\hline \multirow[t]{2}{*}{ Current tenure } & $0.000967 *$ & 0.000589 \\
\hline & $(0.000586)$ & $(0.000682)$ \\
\hline \multirow[t]{2}{*}{ Union member } & $0.0277 * * *$ & $0.0244 * *$ \\
\hline & $(0.0101)$ & $(0.0119)$ \\
\hline \multirow[t]{2}{*}{ Local worker } & 0.0166 & $0.0235^{*}$ \\
\hline & $(0.0104)$ & $(0.0124)$ \\
\hline \multirow[t]{2}{*}{ Police } & 0.00397 & 0.0226 \\
\hline & $(0.0211)$ & $(0.0239)$ \\
\hline \multirow[t]{2}{*}{ Corrections } & 0.00687 & 0.0317 \\
\hline & $(0.0444)$ & $(0.0554)$ \\
\hline \multirow[t]{2}{*}{ Teacher } & $-0.0255^{*}$ & -0.0139 \\
\hline & $(0.0140)$ & $(0.0166)$ \\
\hline \multirow[t]{2}{*}{ School } & -0.0218 & -0.00174 \\
\hline & $(0.0143)$ & $(0.0166)$ \\
\hline \multirow[t]{2}{*}{ University } & $0.0578 * * *$ & $0.0618 * * *$ \\
\hline & $(0.0173)$ & $(0.0208)$ \\
\hline \multirow[t]{2}{*}{ Age } & $0.0138 * * *$ & $0.0145 * * *$ \\
\hline & $(0.00332)$ & $(0.00442)$ \\
\hline \multirow[t]{2}{*}{ Age squared } & $-0.000153 * * *$ & $-0.000147 * * *$ \\
\hline & $(3.66 \mathrm{e}-05)$ & $(4.80 \mathrm{e}-05)$ \\
\hline \multirow[t]{2}{*}{ Female } & $0.0296 * * *$ & $0.0372 * * *$ \\
\hline & $(0.0101)$ & $(0.0120)$ \\
\hline \multirow[t]{2}{*}{ Black } & $-0.131 * * *$ & $-0.103 * * *$ \\
\hline & $(0.0153)$ & $(0.0207)$ \\
\hline \multirow[t]{2}{*}{ Asian } & -0.0119 & -0.0516 \\
\hline & $(0.0268)$ & $(0.0327)$ \\
\hline
\end{tabular}


Table 5 (cont.). Relationship between Select Characteristics and Having Any Retirement Savings

\begin{tabular}{lcc}
\hline & \multicolumn{2}{c}{ Specification } \\
\cline { 2 - 3 } Variables & Full sample & Married only \\
\hline Other & -0.0199 & 0.0149 \\
College degree & $(0.0264)$ & $(0.0319)$ \\
Professional degree & $0.0789^{* * *}$ & $0.0517^{* * *}$ \\
Spouse has college degree & $(0.0127)$ & $(0.0157)$ \\
& $0.107^{* * *}$ & $0.0568^{* * *}$ \\
Spouse has professional degree & $(0.0139)$ & $(0.0173)$ \\
& & $0.0537^{* * *}$ \\
Spouse's relative monthly earnings & & $(0.0132)$ \\
Spouse in private sector & & $0.0681^{* * *}$ \\
Spouse in public sector & & $(0.0155)$ \\
& & $8.99 \mathrm{e}-05^{* * *}$ \\
Married & & $(2.26 \mathrm{e}-05)$ \\
Constant & & $0.112^{* * *}$ \\
& & $(0.0138)$ \\
Observations & & $0.0680^{* * *}$ \\
R-squared & & $(0.0160)$ \\
\hline
\end{tabular}

Notes: Robust standard errors are in parentheses. Stars indicate statistical significance: $* * *<0.01, * *<0.05$, * $<0.10$.

Sources: Authors' estimates from the SIPP 2003-2012; and the PPD 2003-2012. 
Figure 1. Percentage of Employees with Social Security Coverage over Time, 2003-2012

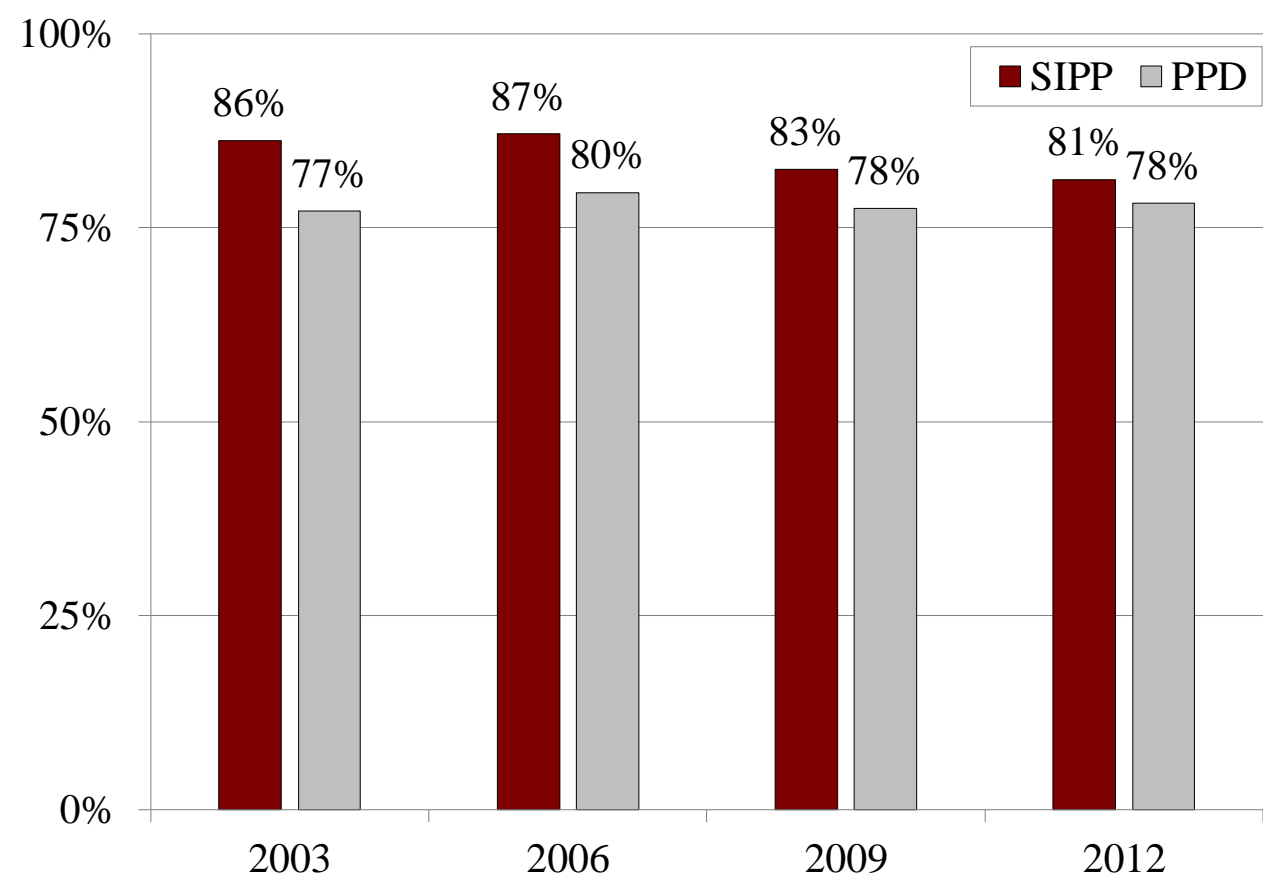

Sources: Authors' estimates from the SIPP 2003-2012; and the PPD 2003-2012.

Figure 2. Occupational Distribution of Analysis Sample, 2003-2012

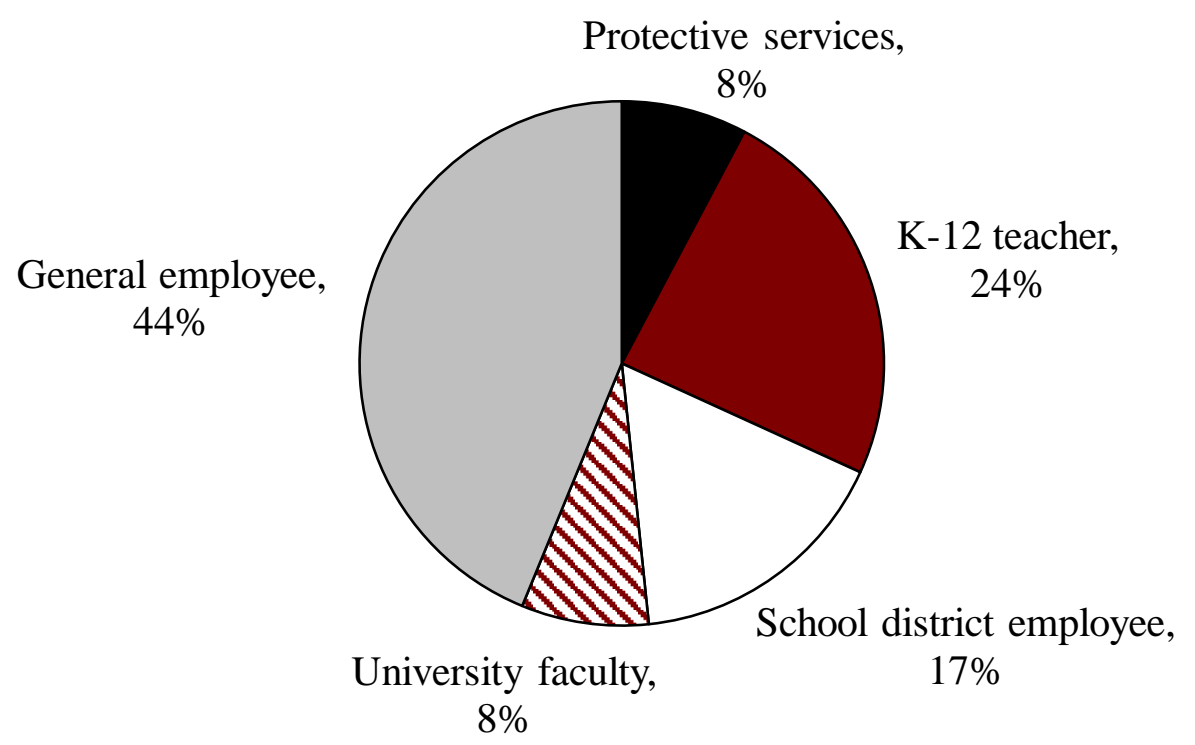

Note: Protective services includes police, fire, and corrective workers.

Sources: Authors' estimates from the SIPP 2003-2012; and the PPD 2003-2012. 


\section{RECENT WORKING PAPERS FROM THE CENTER FOR RETIREMENT RESEARCH AT BOSTON COLLEGE}

How Much Taxes Will Retirees Owe on Their Retirement Income?

Anqi Chen and Alicia H. Munnell, November 2020

A Behavioral Economics Assessment of SSDI Earnings Reporting Documents

Denise Hoffman, Jonah Deutsch, and Britta Seifert, November 2020

How Accurate Are Retirees' Assessments of Their Retirement Risk?

Wenliang Hou, July 2020

Is Nontraditional Work at Older Ages Associated with Better Retirement Security?

Matthew S. Rutledge and Gal Wettstein, July 2020

New Insights on Self-Employment of Older Adults in the United States

Joelle Abramowitz, July 2020

What Jobs Do Employers Want Older Workers to Do?

Alicia H. Munnell, Gal Wettstein, and Abigail N. Walters, June 2020

Technological Innovation and Labor Income Risk

Leonid Kogan, Dimitris Papanikolaou, Lawrence D. W. Schmidt, and Jae Song, June 2020

Are Older Nontraditional Workers Able to Find Health and Retirement Coverage?

Matthew S. Rutledge, March 2020

Employer Perceptions of Older Workers - Surveys from 2019 and 2006

Alicia H. Munnell and Gal Wettstein, March 2020

Are Homeownership Patterns Stable Enough to Tap Home Equity?

Alicia H. Munnell, Abigail N. Walters, Anek Belbase, and Wenliang Hou, January 2020

The Impact of the Minimum Wage on DI Participation

Gary V. Engelhardt, January 2020

Scheduling Uncertainty and Employment of Young Adults with Disabilities

Dara Lee Luca and Purvi Sevak, January 2020

Wages and the Value of Nonemployment

Simon Jäger, Benjamin Schoefer, Samuel Young, and Josef Zweimüller, January 2020

All working papers are available on the Center for Retirement Research website

(https://crr.bc.edu) and can be requested bye-mail (crr@bc.edu) or phone (617-552-1762). 